\title{
The role of culture in quality improvement in the intensive care unit: A literature review
}

\author{
Kim Lam Soh ${ }^{1,2,3}$, Kim Geok Soh ${ }^{4}$, Patricia M. Davidson² \\ 1. Department of Medicine, Faculty of Medicine and Health Sciences, University Putra Malaysia, Malaysia. 2. Centre for \\ Cardiovascular and Chronic Care, Faculty of Nursing, Midwifery and Health, University of Technology Sydney, Australia. 3. \\ School of Nursing and Midwifery, Curtin Health Innovation Research Institute, Curtin University, Australia. 4. Department \\ of Sport Studies, Faculty of Education/Sport Academy, University Putra Malaysia, Malaysia
}

Correspondence: Patricia M Davidson. Address: Centre for Cardiovascular and Chronic Care, Faculty of Nursing, Midwifery and Health, University of Technology Sydney, Australia. E-mail: patriciamary.davidson@uts.edu.au

Received: April 29, 2012

DOI : $10.5430 /$ jha.v2n2p97
Accepted: December 30, 2012

URL: http://dx.doi.org/10.5430/jha.v2n2p97

Online Published: January 21, 2013

\begin{abstract}
Improving the quality of patient care and patient outcomes is a major concern internationally. In a developing health care system, implementing quality improvement is challenging due not only to resource and workforce issues but also cultural factors. Using the method of a focused literature review, this paper discusses the importance of assessing a societal view of culture, social mores and customs, and power relationships in quality improvement activities using the intensive care unit as an exemplar. We conclude that implementing quality improvement strategies in a developing health care system needs to address the broader perspectives of social and cultural systems particularly hierarchical relationships and issues of non-disclosure.
\end{abstract}

\section{Key words}

Cross cultural, Intensive care unit, Literature review, Quality improvement

\section{I ntroduction}

Globalization is a worldwide phenomenon and there has been widespread movement of populations, changing the social and cultural framework of many cultures ${ }^{[1-3]}$. In hospitals, quality improvement projects strive to improve patient care. An environment that supports and enables optimal patient outcomes is dependent on achieving a culture of trust, reporting, transparency and commitment to change ${ }^{[4]}$. Many of the quality improvement models are developed in the West and then 'exported' to developing countries with minimal evaluation of cultural competence ${ }^{[5]}$. Failing to consider cultural views such as an emphasis on hierarchy can limit the capacity to implement a range of approaches, particularly those emphasizing empowerment and challenging inappropriate behaviours ${ }^{[6]}$.

The workplace culture term is typically used in quality improvement parlance ${ }^{[7-9]}$ and applied to discrete organizational factors ${ }^{[10,11]}$. Quality improvement is based on empowerment, transparency and accountability ${ }^{[4,12]}$. The importance of workplace culture ${ }^{[7]}$ and identifying the intensive care unit (ICU) ${ }^{[13]}$ as a microcosm have been undertaken, yet to date there has been limited discussion of the notion of culture as it relates to specific countries and ethnic groups as a factor in organizational change. 
Culture is shaped by multiple influences, such as race, ethnicity, nationality, language and gender, but also extends to socioeconomic status, physical and mental ability, sexual orientation and occupation, among others ${ }^{[14]}$. Collectively, these influences can be described as "sociocultural factors" which shape our values, form our belief systems and motivate our behaviors ${ }^{[14]}$.

Sociocultural differences among patients, health care providers and the health care system are seen by health care experts as potential causes for disparities ${ }^{[14]}$. These differences may possibly also influence the providers' decision-making ${ }^{[14]}$. A comprehensive understanding of cultural dimensions is needed because the key differences that separate ethnic groups have strong cultural implications for management ${ }^{[15]}$.

An understanding of culture is important in determining how an individual adapts and functions within an organizational context ${ }^{[16]}$. Knowledge, attitudes and beliefs pertaining to culture may influence the roles an individual performs in a given situation ${ }^{[17]}$.

Appreciating cultural values is also important for health care providers to create systems, processes and a workforce capable of delivering the highest quality care to individuals regardless of race, ethnicity, and culture or language proficiency ${ }^{[18]}$. This is particularly important due to cultural diversity caused by high international migration, estimated at 214 million in the world ${ }^{[19]}$. Asia was estimated to host the second largest migrant population (61 million) after Europe in $2010^{[19]}$. Therefore there is a need to develop coordinated approaches to address the health implications of modern migration $^{[20]}$.

More than 80 percent of the world's population lives in the more than 100 developing countries ${ }^{[21]}$. Developing countries are classified as those with low or middle per capita Gross National Product (GNP) plus five high-income economies Hong Kong (China), Israel, Kuwait, Singapore and United Arab Emirates,- because of their economic structure or official opinions of their governments ${ }^{[21]}$. Several countries with transitional economies are sometimes considered developing based on their low/middle per capita income, and other times developed based on their high levels of industrialization ${ }^{[21]}$.

Table 1. List of MeSH keywords used for the search strategies

\begin{tabular}{ll}
\hline Set & Mesh keywords \\
\hline 1 & Culture/ or culture.mp. or ethnology.mp. or Ethnology/ or Cross-Cultural Comparison/ or cross cultural.mp. \\
& or cultural characteristics.mp. or Cultural Characteristics/ or cultural diversity.mp. or Cultural Diversity/ or \\
& cultural anthropology.mp. or Anthropology, Cultural/ or ethnic groups.mp. or Ethnic Groups/ cultural factor \\
2 & "Quality of Health Care"/ or Quality Assurance, Health Care/ or quality improvement.mp. or Total Quality \\
& Management/ or "Outcome and Process Assessment (Health Care)"/or "Outcome Assessment (Health \\
& Care)"/ or health care outcome.mp. \\
& Intensive care.mp. or Intensive Care Units/ or Intensive Care/ or Critical Care/ \\
\hline
\end{tabular}

The emphasis on quality improvement initiatives in the developing world is crucial for improving global cooperation ${ }^{[22]}$. Scrutinizing common cross cultural meanings attributed to individuals may vary from culture to culture and must be incorporated into the understanding of the way culture is related to individual differences in behavior ${ }^{[23]}$. A mismatch of socio-cultural factors can result in different approaches in management strategies ${ }^{[24]}$ especially when it involves a business organization ${ }^{[25]}$. Studying the impact of different cultures on the practice of health care practitioners will enable the providers to understand and plan their approaches before implementing change in their organizations.

This article argues the importance of addressing broader cultural and social factors when implementing a quality improvement methodology, particularly in emerging economies. Although this is critically important in all areas of hospitals, the high rates of preventable conditions in the intensive care unit (ICU), such as catheter related blood stream 
infections and ventilator associated pneumonia, emphasize the importance of reflecting and modifying clinical practices to improve outcomes ${ }^{[26]}$. In order to address these factors, a focused literature review was undertaken.

\section{Methods}

A search was undertaken of electronic databases to identify relevant literature. Cumulative Index of Nursing and Allied Health Literature (CINAHL) 1982 - August 2010; Medline 1950 - August 2010; Embase 1988 - August 2010; PsycINFO 1806 - August 2010 were searched using MeSH key words for culture, quality improvement and intensive care unit (Table 1). Assistance in designing the literature search strategies for all databases was provided by a health librarian. Articles were considered relevant if they reported a societal culture perspective on quality improvement projects in adult ICUs. To reduce gaps in the automated search caused by indexing lags in the electronic databases, a manual search was undertaken by the authors. This search included reviewing references from the retrieved articles and also searching from other databases, such as Google Scholar, Mednar and Scopus. The reference list from each retrieved article was in turn scanned for additional articles.

\section{Results}

After a detailed search and examination, no articles were identified discussing this issue as shown in Figure 1. In spite of the limited data retrieved, the key issues contributing to incorporating issues of culture in quality improvement initiatives are discussed below.

Figure 1. Flowchart of study selection process

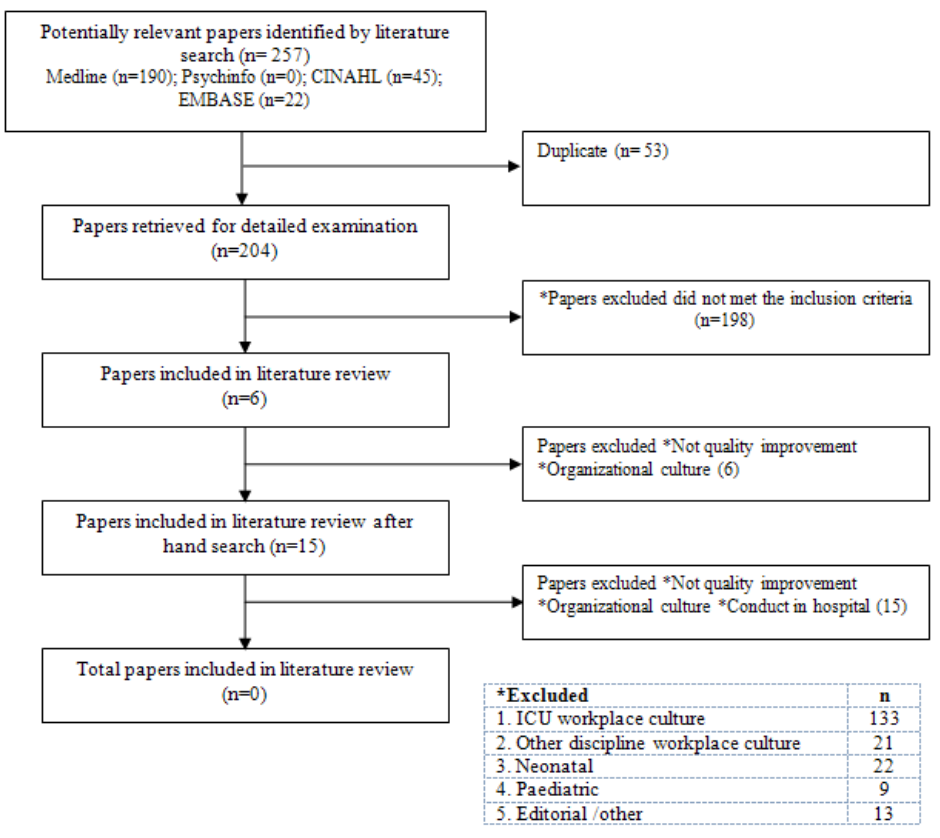

\section{Discussion}

\subsection{I mportance of assessing a societal view of culture}

The limited information on the influence of societal culture on acceptance of quality improvement processes in the ICU indicates that there is a gap in the current knowledge. This is particularly the case due to the rapid technological innovation 
and introduction of ICUs in the developing world ${ }^{[27,28]}$. The majority of retrieved articles focused on organizational culture $^{[12,29-39]}$. The others were conducted either in the general hospital and not ICU, or were not quality improvement reports ${ }^{[40-44]}$.

The complexity of health care systems and the interdependence among clinicians and systems are well documented ${ }^{[45,46]}$. The ICU is a complicated and multifaceted organizational structure, involving evaluation of complex and multilevel interventions; hence, an interdisciplinary approach is required to optimize the effectiveness of interventions ${ }^{[47]}$. Understanding cross-culture influences in this setting is useful for patient management and collaboration among the health care workers.

The increased diversity of patients and health care providers around the world due to international migration has increased the need to gain far greater understanding of cross-cultural influences ${ }^{[48]}$. Health care workers have a broad range of perspectives on health which are often influenced by their social or cultural backgrounds. Moreover, current workplaces demand a workforce that is culturally competent to improve the quality of care provided and eliminate racial/ethnic disparities in the care ${ }^{[18,48]}$.

Cultural competence is seen as a method to increase access to quality of care for all patient populations aiming to change a one-size-fits-all system to one more responsive to the needs of diverse patients ${ }^{[18,49]}$. The health care workforce needs to understand the relationship between cultural beliefs and behavior, and develop the skills to improve the quality of care they provide to these diverse populations ${ }^{[18]}$. The essential component in culturally competent care includes diversity among staff and providers ${ }^{[18]}$. Understanding individual cultural values will help to improve the care provided and collaboration among the health care workers in the ICU where the importance of team work is important in achieving optimal patient outcomes ${ }^{[50]}$.

\subsection{Social mores and customs}

The ideal organization is based on good interpersonal relationships, rather than individual rights, with leadership as part of a natural hierarchy ${ }^{[24]}$. In many cultures where hierarchy and social desirability predominate ${ }^{[51,52]}$, implementing quality improvement may be more challenging ${ }^{[5]}$. In some cultures the capacity of a manager to work with a team is more important than individual expertise and the commitment and loyalty to the group carries more weight than the ability to perform tasks as an individual ${ }^{[15]}$.

Understanding cultural values in this situation is important because sensitivities surface in many guises ${ }^{[15]}$. Showing mutual respect is important in all Asian cultures, and there is a carefully calibrated scale of social rank ${ }^{[15]}$. An outsider would need to be sensitized to these cultural dynamics to read the social situation correctly, because sometimes an insensitive technocrat will not be accepted, regardless of how clever she/he may be ${ }^{[15]}$.

Many Asian cultures share the concept of maintaining balance. When this balance is impeded by the leader or staff, it creates conflict which is seen as a negative ${ }^{[51]}$. In a collectivist culture, conflict situations are primarily concerned with maintaining relationships with others, whereas individualists are mainly related to achieving justice ${ }^{[33]}$. Collectivism with an emphasis on culture sees the environment as more or less fixed or a stable norm, but obligations, duties and themselves as changeable to "fit in" ${ }^{[23]}$.

In the collectivist culture, lying is an acceptable behavior if it saves face or helps the in-group ${ }^{[23]}$. Conflict usually occurs when someone does not understand the clash between cultures caused by the differences between individualist values, collective values, power relationships, and feelings of certainty/uncertainty ${ }^{[51]}$. Therefore, in collectivist cultures, such as Thailand, Malaysia, Singapore, Indonesia, Taiwan, Korea and Hong Kong ${ }^{[54]}$, there is a need to consider the social perspectives before implementing quality improvement strategies in the ICU. 


\subsection{Power relationships impacting the workplace}

Power distance is the degree to which unequal distribution of power and wealth is tolerated, determined by the hierarchy in workplaces and distance between social strata. Communications are likely to be through the command chain than direct $^{[22,51]}$. The responsibility for making decisions is given to management and is not team-oriented ${ }^{[55]}$. The leader accepts responsibility for the development and well-being of the employees, and in return expects their obedience and personal loyalty ${ }^{[24]}$. Therefore, workers in highly collective and hierarchical models are group oriented, respect elders and hierarchy, emphasize loyalty and consensus and are concerned with harmony in relationships ${ }^{[56]}$. Disagreement, if expressed, will be done indirectly to avoid overt confrontation and arouse discomfort in other people ${ }^{[56]}$. This explains why in a very hierarchical structure workplace people are more inclined to state what should be said rather than what they really feel. This is in contrast to the Western preference of open disclosure ${ }^{[57]}$.

The disadvantage of working in a society with a marked power differential is that the workers are very cautious to express their thoughts. Therefore, for them to keep balance, work in harmony and also keep their jobs, the majority choose silence instead of unveiling their latent talents or creativity. As a result, the workers in these countries are less empowered vis-à-vis their Western compatriots. Empowerment will create more confidence for people to act and foster a sense of job ownership ${ }^{[25]}$.

A study on attitudes towards working situations among managers from Australia and Japan found respondent bias and attributed it to social desirability ${ }^{[58]}$. The authors also discovered that response styles among managers from Asian cultures tended to be modest and that they responded cautiously ${ }^{[59]}$. This reflects Asian cultures, which tend to be very careful about commenting or opposing others' views in order to maintain the balanced feeling as discussed above. This indicates that an individual with a different cultural background may not express his thoughts in order to keep the balance and his social desirability.

\subsection{Recommendations for quality improvement in Asian ICU}

The ICU is a complicated and multifaceted organizational structure involving evaluation of complex and multilevel interventions; therefore, an interdisciplinary approach is essential to optimize the effectiveness of interventions ${ }^{[47]}$. A culture of collaboration and teamwork is important prior to implementing any quality improvement measure. Establishing a quality system in any organization addressing culture is critical in achieving and sustaining improvement ${ }^{[25,60]}$. The final result will benefit the organization and patients through improving and sustaining the health care provided.

This paper acknowledges that the fact that no articles were identified which met the inclusion criteria is a potential limitation. However this identifies that there has been very little work in this area, and that the subject should be better explored in the future. The failure to identify appropriate articles does not dismiss the importance of investigating this issue. In the field of business, culture is noted as moderating the success of particular initiatives ${ }^{[61]}$.

The paper proposes that cultural ethnicity is an important consideration before implementing quality improvement initiatives in non-Western countries. Incompatible cultural values may harm constructive group processes, and then negatively affect the well-being of the team members as well as their performance ${ }^{[62]}$ in implementing quality improvement initiatives ${ }^{[23]}$.

\section{Conclusion}

Addressing cultural influences in quality improvement projects is crucial for improving patient management, promoting effective collaboration and teamwork among the health care providers in the complex milieu of the ICU. Issues of hierarchical relationships and non-disclosure can hinder Western models of quality improvement. Considering the influence of social cultural aspects as well as organizational factors are likely to be important factors when implementing 
quality improvement initiatives, particularly in areas such as ICU where teamwork and accountability are of high importance.

\section{References}

[1] Bresman, H., Birkinshaw, J.,Nobel, R., Knowledge transfer in international acquisitions. Journal of International Business Studies. 2010; 41(1): 5-20. http://dx.doi.org/10.1057/jibs.2009.56

[2] Pérez-Nordtvedt, L., Kedia, B. L., Datta, D. K.,Rasheed, A. A., Effectiveness and efficiency of cross-border knowledge transfer: An empirical examination. Journal of Management Studies. 2008; 45(4): 714-744.

http://dx.doi.org/10.1111/j.1467-6486.2008.00767.x

[3] Naor, M., Linderman, K.,Schroeder, R., The globalization of operations in Eastern and Western countries: Unpacking the relationship between national and organizational culture and its impact on manufacturing performance. Journal of Operations Management. 2010; 28(3): 194-205. http://dx.doi.org/10.1016/j.jom.2009.11.001

[4] Leape, L., Berwick, D., Clancy, C., Conway, J., Gluck, P., Guest, J., Lawrence, D., Morath, J., O'Leary, D., O'Neill, P., Pinakiewicz, D.,Isaac, T., Transforming healthcare: A safety imperative. Quality and Safety in Health Care. 2009; 18(6): 424-428. PMid:19955451 http://dx.doi.org/10.1136/qshc.2009.036954

[5] Soh, K. L., Davidson, P. M., Leslie, G., DiGiacomo, M.,Soh, K. G., Nurses' perceptions of standardised assessment and prevention of complications in an ICU. Journal of Clinical Nursing. 2012. http://dx.doi.org/10.1111/jocn.12017

[6] Carlton, E., Gartner, A., Boehm, H., Styles, A., Thibault, J., Improving outcomes with the Quality and Safety Investigator program. Nursing Management. 2012; 43(8): 22-26. PMid:22846696 http://dx.doi.org/10.1097/01.NUMA.0000416410.68355.f9

[7] Wilson, V. J., McCormack, B. G.,Ives, G., Understanding the workplace culture of a special care nursery. Journal of Advanced Nursing. 2005; 50(1): 27-38. PMid:15788063 http://dx.doi.org/10.1111/j.1365-2648.2004.03346.x

[8] Nieva, V. F.,Sorra, J., Safety culture assessment: A tool for improving patient safety in healthcare organizations. Quality and Safety in Health Care. 2003; 12(suppl 2): ii17-ii23. PMid:14645891 http://dx.doi.org/10.1136/qhc.12.suppl_2.ii17

[9] Reiman, T., Pietikainen, E.,Oedewald, P., Multilayered approach to patient safety culture. Quality and Safety in Health Care. 2010; 19(5): e20-e24. PMid:20724396 http://dx.doi.org/10.1136/qshc.2008.029793

[10] Smith, J. R.,Donze, A., Assessing environmental readiness: First steps in developing an evidence-based practice implementation culture. Journal of Perinatal and Neonatal Nursing. 2010; 24(1): 61-71. PMid:20147832

[11] Sleutel, M. R., Climate, culture, context, or work environment?: Organizational factors that influence nursing practice. Journal of Nursing Administration. 2000; 30(2): 53-58. PMid:10689396 http://dx.doi.org/10.1097/00005110-200002000-00002

[12] Kahn, J. M.,Fuchs, B. D., Identifying and implementing quality improvement measures in the intensive care unit. Current Opinion in Critical Care. 2007; 13(6): 709-713. PMid:17975395 http://dx.doi.org/10.1097/MCC.0b013e3282flbe5c

[13] Huang, D. T., Clermont, G., Sexton, B., Karlo, C. A., Miller, R. G., Weissfeld, L. A., Rowan, K. M.,Angus, D. C., Perceptions of safety culture vary across the intensive care units of a single institution. Critical Care Medicine. 2007; 35(1): 165-176. PMid:17110876 http://dx.doi.org/10.1097/01.CCM.0000251505.76026.CF

[14] Betancourt, J. R., Green, A. R.,Carrillo, J. E. Cultural competence in health care: Emerging frameworks and practical approaches. 2002. Commonwealth Fund, Quality of Care for Underserved Populations.

[15] Sendut, H., Managing in a multicultural society: The Malaysian experience Malaysian Management Review. 1991; 26(1): 61-69.

[16] Schneider, B., The people make the place. Personnel Psychology. 1987; 40(3): 437-453. http://dx.doi.org/10.1111/j.1744-6570.1987.tb00609.x

[17] The University of Michigan. Safety culture [Internet]. 2002. Available from: http://www.oseh.umich.edu/research/safety-culture.shtml. [Cited 4 February 2011].

[18] Betancourt, J. R., Green, A. R., Carrillo, J. E.,Park, E. R., Cultural competence and health care disparities: key perspectives and trends. Health Affairs. 2005; 24(2): 499-505. PMid:15757936 http://dx.doi.org/10.1377/hlthaff.24.2.499

[19] United Nations Department of Economic and Social Affairs Population Division. Trends in international migrant stock: The 2008 revision. 2009. New York: UNDESA.

[20] Zimmerman, C., Kiss, L.,Hossain, M., Migration and health: A framework for 21st century policy-making. PLoS Medicine. 2011; 8(5): 1-7. PMid:21629681 http://dx.doi.org/10.1371/journal.pmed.1001034

[21] The World Bank. Beyond economic growth student book: Glossary [Internet]. 2004. Available from: http://www.worldbank.org/depweb/english/beyond/global/glossary.html\#16. [cited 7 October 2010];

[22] Jones, M. L., Hofstede - Culturally questionable? [Internet]. 2007. Available from: http://ro.uow.edu.au/cgi/viewcontent.cgi?article=1389\&context=commpapers. [cited 8 Aug 2010]; 
[23] Triandis, H. C.,Suh, E. M., Cultural influences on personality. Annual Review of Psychology. 2002; 53(1): $133-160$. PMid:11752482 http://dx.doi.org/10.1146/annurev.psych.53.100901.135200

[24] Macoby, M., Creating quality cultures in the east and west. Research Technology Management. 1994; 37(1): 57-59.

[25] Khoo, H. H., Tan, K. C., Managing for quality in the USA and Japan: Differences between the MBNQA, DP and JQA. The TQM Magazine. 2003; 15(1): 14-24. http://dx.doi.org/10.1108/09544780310454402

[26] Berenholtz, S. M., Pham, J. C., Thompson, D. A., Needham, D. M., Lubomski, L. H., Hyzy, R. C., Welsh, R., Cosgrove, S. E., Sexton, J. B., Colantuoni, E., Watson, S. R., Goeschel, C. A.,Pronovost, P. J., Collaborative cohort study of an intervention to reduce ventilator-associated pneumonia in the intensive care unit. Infection Control and Hospital Epidemiology. 2011; 32(4): 305-314. PMid:21460481 http://dx.doi.org/10.1086/658938

[27] Rosenthal, V., Ramachandran, B., Villamil-Gómez, W., Armas-Ruiz, A., Navoa-Ng, J., Matta-Cortés, L., Pawar, M., Nevzat-Yalcin, A., Rodríguez-Ferrer, M.,Yıldızdaş, R., Impact of a multidimensional infection control strategy on central line-associated bloodstream infection rates in pediatric intensive care units of five developing countries: Findings of the International Nosocomial Infection Control Consortium (INICC). Infection. 2012; 40(4): 415-423. PMid:22371234 http://dx.doi.org/10.1007/s15010-012-0246-5

[28] Rosenthal, V., Todi, S., Álvarez-Moreno, C., Pawar, M., Karlekar, A., Zeggwagh, A., Mitrev, Z., Udwadia, F., Navoa-Ng, J.,Chakravarthy, M., Impact of a multidimensional infection control strategy on catheter-associated urinary tract infection rates in the adult intensive care units of 15 developing countries: findings of the International Nosocomial Infection Control Consortium (INICC). Infection. 2012; 40(5): 517-526. PMid:22711598 http://dx.doi.org/10.1007/s15010-012-0278-x

[29] Berriel-Cass, D., Adkins, F. W., Jones, P., Fakih, M. G., Berriel-Cass, D., Adkins, F. W., Jones, P.,Fakih, M. G., Eliminating nosocomial infections at Ascension Health. Joint Commission Journal on Quality \& Patient Safety. 2006; 32(11): 612-20. PMid:17120920

[30] Clemmer, T. P., Spuhler, V. J., Oniki, T. A., Horn, S. D., Clemmer, T. P., Spuhler, V. J., Oniki, T. A.,Horn, S. D., Results of a collaborative quality improvement program on outcomes and costs in a tertiary critical care unit. Critical Care Medicine. 1999; 27(9): 1768-1774. PMid:10507596 http://dx.doi.org/10.1097/00003246-199909000-00011

[31] Dixon, J. F.,Dixon, J. F., The American Association of Critical Care Nurses standards for establishing and sustaining healthy work environments: Off the printed page and into practice. Critical Care Nursing Clinics of North America. 2008; 20(4): 393-401. PMid:19007705 http://dx.doi.org/10.1016/j.ccell.2008.08.010

[32] Hancock, H. C., Easen, P. R., Hancock, H. C.,Easen, P. R., The decision-making processes of nurses when extubating patients following cardiac surgery: an ethnographic study. International Journal of Nursing Studies. 2006; 43(6): 693-705. PMid:16256118 http://dx.doi.org/10.1016/j.ijnurstu.2005.09.003

[33] Jain, M., Miller, L., Belt, D., King, D., Berwick, D. M., Jain, M., Miller, L., Belt, D., King, D.,Berwick, D. M., Decline in ICU adverse events, nosocomial infections and cost through a quality improvement initiative focusing on teamwork and culture change. Quality and Safety in Health Care. 2006; 15(4): 235-239. PMid:16885246 http://dx.doi.org/10.1136/qshc.2005.016576

[34] Minvielle, E., Aegerter, P., Dervaux, B., Boumendil, A., Retbi, A., Jars-Guincestre, M. C.,Guidet, B., Assessing organizational performance in intensive care units: A French experience. Journal of Critical Care 2008; 23(2): 236-244. PMid:18538217 http://dx.doi.org/10.1016/j.jcrc.2007.11.006

[35] Plost, G.,Nelson, D. P., Empowering critical care nurses to improve compliance with protocols in the intensive care unit. American Journal of Critical Care. 2007; 16(2): 153-156. PMid:17322016

[36] Rosengren, K., Athlin, E., Segesten, K., Rosengren, K., Athlin, E.,Segesten, K., Presence and availability: Staff conceptions of nursing leadership on an intensive care unit. Journal of Nursing Management. 2007; 15(5): 522-9. PMid:17576250 http://dx.doi.org/10.1111/j.1365-2834.2007.00712.x

[37] Shortell, S. M., Zimmerman, J. E., Rousseau, D. M., Gillies, R. R., Wagner, D. P., Draper, E. A., Knaus, W. A., Duffy, J., Shortell, S. M., Zimmerman, J. E., Rousseau, D. M., Gillies, R. R., Wagner, D. P., Draper, E. A., Knaus, W. A.,Duffy, J., The performance of intensive care units: Does good management make a difference? Medical Care. 1994; 32(5): 508-525. PMid:8182978 http://dx.doi.org/10.1097/00005650-199405000-00009

[38] Stein-Parbury, J.,Liaschenko, J., Understanding collaboration between nurses and physicians as knowledge at work. American Journal of Critical Care. 2007; 16(5): 470-477. PMid:17724244

[39] Manley, K., Organisational culture and consultant nurse outcomes: Part 2. Nurse outcomes. Nursing Standard. 2000; 14(37): 34-39.

[40] Chen, F. F., What happens if we compare chopsticks with forks? The impact of making inappropriate comparisons in cross-cultural research. Journal of Personality and Social Psychology. 2008; 95(5): 1005-1018. PMid:18954190 http://dx.doi.org/10.1037/a0013193 
[41] Sirio, C. A., Tajimi, K., Tase, C., Knaus, W. A., Wagner, D. P., Hirasawa, H., Sakanishi, N., Katsuya, H.,Taenaka, N., An initial comparison of intensive care in Japan and the United States. Critical Care Medicine. 1992; 20(9): 1207-1215. PMid:1521435 http://dx.doi.org/10.1097/00003246-199209000-00006

[42] Sirio, C. A., Tajimi, K., Taenaka, N., Ujike, Y., Okamoto, K.,Katsuya, H., A cross-cultural comparison of critical care delivery. Chest. 2002; 121(2): 539-548. PMid:11834670 http://dx.doi.org/10.1378/chest.121.2.539

[43] Einav, S., Soudry, E., Levin, P. D., Grunfeld, G. B.,Sprung, C. L., Intensive care physicians' attitudes concerning distribution of intensive care resources a comparison of Israeli, North American and European cohorts. Intensive Care Medicine. 2004; 30(6): 1140-1143. PMid:15067504 http://dx.doi.org/10.1007/s00134-004-2273-x

[44] Cheng, F., Critical care ethics in Hong Kong: Cross-cultural conflicts as east meets west. Journal of Medicine and Philosophy. 1998; 23(6): 616-627. PMid:10190844 http://dx.doi.org/10.1076/jmep.23.6.616.2554

[45] Ferlie, E., Fitzgerald, L., Wood, M.,Hawkins, C., The nonspread of innovations: the mediating role of professionals. The Academy of Management Journal. 2005; 48(1): 117-134. http://dx.doi.org/10.5465/AMJ.2005.15993150

[46] Hughes, R. Tools and strategies for quality improvement and patient safety, in Patient safety and quality: An evidence-based handbook for nurses, 2008; 1-39.

[47] Hillman, K., Chen, J.,May, E., Complex intensive care unit interventions. Critical Care Medicine. 2009; $37(1)$ : S102-S106. PMid:19104208 http://dx.doi.org/10.1097/CCM.0b013e3181920f18

[48] Wild, V., Migration and health: Discovering new territory for bioethics. The American Journal of Bioethics. 2012; 12(9): 11-13. PMid:22881846 http://dx.doi.org/10.1080/15265161.2012.692439

[49] Clancy, C., Brach, C.,Abrams, M., Assessing patient experiences of providers' cultural competence and health literacy practices: CAHPS ${ }^{\circledR}$ item sets. Medical Care. 2012; 50(9 Suppl 2): S1-S2. PMid:22895224 http://dx.doi.org/10.1097/MLR.0b013e3182641e7f

[50] Kross, E. K.,Curtis, J. R., ICU clinicians' perceptions of appropriateness of care and the importance of nurse-physician collaboration. Archives of Internal Medicine. 2012; 172(11): 889-890. PMid:22688994 http://dx.doi.org/10.1001/archinternmed.2012.1671

[51] Swierczek, F. W., Culture and conflict in joint ventures in Asia. International Journal of Project Management. 1994; $12(1): 39-47$. http://dx.doi.org/10.1016/0263-7863(94)90008-6

[52] Harrowing, J. N., Mill, J., Spiers, J., Kulig, J.,Kipp, W., Culture, context and community: Ethical considerations for global nursing research. International Nursing Review. 2010; 57(1): 70-77. PMid:20487477 http://dx.doi.org/10.1111/j.1466-7657.2009.00766.x

[53] Ohbuchi, K.-I., Fukushima, O.,Tedeschi, J. T., Cultural values in conflict management. Journal of Cross-Cultural Psychology. 1999; 30(1): 51-71. http://dx.doi.org/10.1177/0022022199030001003

[54] Hofstede, G., The cultural relativity of organizational practices and theories. Journal of International Business Studies. 1983; 14(2): 75-89. http://dx.doi.org/10.1057/palgrave.jibs.8490867

[55] Sin, G.,Jain, H., Learning from the Japanese in Malaysia. Euro-Asia Business Review. 1987; 6(1): $41-45$.

[56] Asma, A. Going Glocal: Cultural Dimensions in Malaysian Management, 1996, Malaysian Institute of Management: Kuala Lumpur. PMid:8938918

[57] Garrouste-Orgeas, M., Philippart, F., Bruel, C., Max, A., Lau, N.,Misset, B., Overview of medical errors and adverse events. Annals of Intensive Care. 2012; 2(1): 2. PMid:22339769 http://dx.doi.org/10.1186/2110-5820-2-2

[58] Stening, B. W.,Everett, J. E., Direct and stereotype cultural differences. Journal of Cross-Cultural Psychology. 1979; 10(2): 203-220. http://dx.doi.org/10.1177/0022022179102007

[59] Stening, B. W.,Everett, J. E., Response styles in a cross-cultural managerial study. The Journal of Social Psychology. 1984; 122(2): 151-156. http://dx.doi.org/10.1080/00224545.1984.9713475

[60] Mak, W. M., Cultivating a quality mind-set. Total Quality Management. 1999; 10(4): 622-626. http://dx.doi.org/10.1080/0954412997604

[61] Jiang, C. X., Chua, R. Y. J., Kotabe, M.,Murray, J. Y., Effects of cultural ethnicity, firm size, and firm age on senior executives' trust in their overseas business partners: Evidence from China. Journal of International Business Studies. 2011; 42(9): $1150-1173$. http://dx.doi.org/10.1057/jibs.2011.35

[62] Messick, D. M.,Mackie, D. M., Intergroup relations. Annual Review of Psychology. 1989; 40(1): 45-81. PMid:2648982 http://dx.doi.org/10.1146/annurev.ps.40.020189.000401 